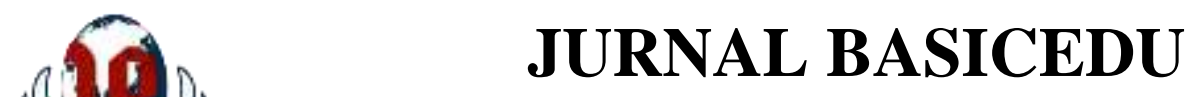

Volume 5 Nomor 6 Tahun 2021 Halaman 5195 - 5203

Research \& Learning in Elementary Education

https://jbasic.org/index.php/basicedu

$P$ AHLAWAN

\title{
Analis TPACK (Technological Pedagogical Content Knowledge) Guru Sekolah Dasar dalam Pembelajaran di Masa Pandemi Covid-19 di Surakarta
}

\section{Dila Putri Maharani ${ }^{1 凶}$, Hengki Hermawan ${ }^{2}$, Desi Tri Wulandari ${ }^{3}$, Nadia Yuli Ismawarti ${ }^{4}$, Galuh Kancanadana ${ }^{5}$, Ika Candra Sayekti ${ }^{6}$}

Universitas Muhammadiyah Surakarta, Indonesia ${ }^{1,2,3,4,5,6}$

E-mail: a510170169@student.ums.ac.id ${ }^{1}$, a510170097@student.ums.ac.id²,$\underline{\text { a510180056@student.ums.ac.id }}^{3}$, a510180231@ @student.ums.ac.id ${ }^{4}, \underline{\text { a510190076@student.ums.ac.id }}, \underline{\text { ics142@ums.ac.id }}^{6}$

\begin{abstract}
Abstrak
Pendidikan merupakan suatu yang harus didapatkan oleh setiap orang. Dalam pendidikan di sekolah terdapat tiga aspek penting yakni pemberi pengetahuan (guru), penerima (sisiwa) dan pengetahuan itu sendiri. Adanya pandemi Covid 19 menyebabkan pendidikan harus berubah dengan pemberlakuan pembelajaran daring. Sehingga kemampuan seorang tenaga pendidikan dalam mengajar harus dikembangkan. Maka dari itu penelitian ini meneliti tentang kemampuan guru dalam menerapkan kemampuan TPACK nya atau kemampuan yang berkaitan dengan teknologi, pedagogi, konten. Penelitian ini dilaksanakan di Surakarta, subjek yang digunakan dalam penelitian ini ialah guru sekolah dasar di Surakarta yang terdiri dari 5 kecamatan yakni Laweyan, Serengan, Pasar Kliwon, Banjarsari dan Jebres. Setiap kecamatan peneliti mengambil dua sekolahan yakni sekolahan swasta dan negeri. Disetiap sekolah kami mengambil subjek dua guru terdiri dari satu guru kelas atas dan satu guru kelas bawah yang diambil secara acak. Sehingga dalam satu kecamatan ada empat guru dan dalam satu kabupaten terdapat duapuluh guru. Hasil yang didapat dalam penelitian ini adalah semua guru disurakarta menggunakan media whatsap dalam pembelajaran, zoom dan google meet digunakan dalam evaluasi materi. TK, PK, CK, PCK, TPK, TCK dan TPACK Sudah terdapat dalam pengajaran guru di Surakarta. Mereka menggunakan teknologi atau aplikasi WA yang banyak digunakan oleh siswa dan orangtua. Penggunaan video pembelajaran dan zoom meeting dan web meeting satu bulan sekali juga digunakan dalam evaluasi pembelajaran. Hambatan yang dialami oleh responden seperti keluhan kuota internet cepat habis, memori gawai yang cepat penuh, menentukan jadwal tatap muka daring, adapun yang tidak memiliki gawai. Solusi untuk mengatasinya yakni melakukan tatap muka yang singkat, menghapus file-file yang sudah tidak digunakan, membuat video pembelajaran yang tidak terlalu panjang dan dengan kualitas yang rendah namun masih bisa dilihat dan didengar siswa.
\end{abstract}

Kata Kunci: Guru, TPACK, Covid-19

\begin{abstract}
Education is something that everyone should get. In education in schools, there are three important aspects, namely the giver of knowledge (teachers), recipients (students), and knowledge itself. The Covid-19 pandemic has caused education to have to change with the implementation of bold learning. So the ability of an educator in teaching must be developed. Therefore, this study examines the ability of teachers to apply their TPACK abilities or abilities related to technology, pedagogy, content. This research was conducted in Surakarta, the subjects used in this study were elementary school teachers in Surakarta which consisted of 5 sub-districts namely Laweyan, Serengan, Pasar Kliwon, Banjarsari, and Jebres. Each sub-district researcher took two schools, namely private and public schools. In each school, we took the subject of two teachers consisting of one upper-grade teacher and one lower-grade teacher who were randomly selected. So that in one sub-district there are four teachers and in one district there are twenty teachers. The results in this study are all teachers in Surakarta use WhatsApp media in learning, zoom and google meet are used in the material evaluation. Kindergarten, $P K, C K, P C K, T P K, T C K$, and TPACK already exist in teacher teaching in Surakarta. They use technology or WA applications that are widely used by students and parents. The use of learning videos and zoom meetings and once a month web meetings are also used in the evaluation of learning. Obstacles experienced by respondents such as complaints of internet quota running out quickly, device memory filling up quickly, determining a face-toface schedule, and those who do not have a device. The solution to overcome this is to do short face-to-face meetings, delete files that are no longer used, make learning videos that are not too long and of low quality but can still be seen and heard by students. Keywords: Teacher, TPACK, Covid-19
\end{abstract}

Copyright (c) 2021 Dila Putri Maharani, Hengki Hermawan, Desi Tri Wulandari, Nadia Yuli Ismawarti, Galuh Kancanadana, Ika Candra Sayekti

Corresponding author :

Email : a510170169@student.ums.ac.id

DOI $\quad$ : https://doi.org/10.31004/basicedu.v5i6.1501

ISSN 2580-3735 (Media Cetak)

ISSN 2580-1147 (Media Online)

Jurnal Basicedu Vol 5 No 6 Tahun 2021

p-ISSN 2580-3735 e-ISSN 2580-1147 
5196 Analis TPACK (Technological Pedagogical Content Knowledge) Guru Sekolah Dasar dalam Pembelajaran di Masa Pandemi Covid-19 di Surakarta - Dila Putri Maharani, Hengki Hermawan, Desi Tri Wulandari, Nadia Yuli Ismawarti, Galuh Kancanadana, Ika Candra Sayekti

DOI: https://doi.org/10.31004/basicedu.v5i6.1501

\section{PENDAHULUAN}

Pendidikan merupakan salah satu unsur terpenting dalam keberlangsungan hidup masyarakat. Pendidikan menjadikan sarana penting karena dengan adanya pendidikan manusia yang tadinya tidak tahu menjadi tahu, tidak mengerti menjadi mengerti. Selain itu dengan pendidikan dapat terwujudnya masyarakat yang berkarakter, mempunyai perilaku yang baik, serta dapat mengembangkan potensi yang dimiliki manusia. Sesuai dengan UU Sistem Pendidikan Nasional yakni Pendidikan merupakan usaha sadar dan terencana untuk mewujudkan suasana belajar dan proses pembelajaran agar siswa secara aktif mengembangkan potensinya dirinya.

Potensi yang dimiliki dapat dikembangkan, bahkan dapat menjadi bekal kemampuan untuk bertahan hidup (berkarir). Pelaksanaan pendidikan dapat terlaksana di sekolah (formal) atau di keluarga, masyarakat (Informal), lembaga kegiatan belajar masyarakat (non formal). Pelaksanaan pendidikan tentunya terdapat orang pemberi pengetahuan (guru), orang yang menerima pengetahuan atau pembelajaran tersebut (siswa) serta pengetahuan itu sendiri. Pendidikan yang dilaksanakan sekarang berbeda dengan sebelumnya, disebabkan karena pandemi Covid 19. Merebaknya kasus covid 19 menyebabkan tatanan kehidupan berubah. Hal ini berpengaruh keberbagai sektor seperti sektor ekonimi, pendidikan dan sektor lainnya. Bekerja yang semula harus ke kantor berubah harus dari rumah, sehingga memerlukan pembiasaan dan beradaptasi. Kegiatan ini juga harus menimbulkan lockdown diberbagai daerah agar virus covid 19 tidak menyebar luas. Menerapkan berbagai protokol kesehatan yang semula 3M sekarang menjadi $5 \mathrm{M}$ dalam melaksankan kegiatan. Hal ini berpengaruh terhadap ekonomi masyarakat Indonesia tidak luput sektor pendidikan.

Pendidikan yang dilaksanakan di masa pandemi ini bisa dikatakan tiba-tiba, guru atau tenaga pendidik harus bisa segera beradaptasi. Walaupun di dalam kurikulum K-13 guru bukan menjadi pusat dalam pendidikan, tidak dipungkiri dengan adanya guru secara langsung dapat menumbuhkan semangat belajar siswa. Siswa jadi lebih tahu tentang pendidikan yang ditempuh. Hal ini berbeda di masa sekarang siswa merasa lelah dengan pembelajaran daring, dll. Hal tersebut sesuai dengan temuan dari penelitian (Mar'ah, Rusilowati, \& Sumami, 2020, hal. 450) yakni dampak yang dirasakan siswa dalam pembelajaran, 1. siswa merasa dipaksa belajar dalam pembelajaran secara online tanpa adanya sarana dan prasarana yang mendukung, 2. Siswa mengalami jenuh, kehilangan jiwa sosial karena sulitnya berinteraksi dengan orang lain, kemudian 3. Siswa kelas 1 sampai 3 memerlukan pendampingan belajar secara ekstra.

Begitu banyaknya dampak yang terjadi selama pembelajran secara daring karena virus covid-19. Pendidikan yang menghadirkan guru secara langsung merupakan langkah yang tidak akan bisa digantikan, guru mengajar dengan perasaan, kasih, aktif, kreatif, sabar merupakan hal yang menyebabkan anak senang dalam pembelajaran sehingga pembelajaran dapat terjadi dua arah dan tujuan dari pembelajaran tercapai dengan baik. Berbeda dengan masa pandemi Covid 19, guru sudah membuat media pembelajaran video namun siswa tidak memiliki perangkat gawai yang memadai, terkendalanya sinyal, dsb. Sehingga pemberian tugas merupakan salah satu cara yang tepat untuk siswa. Namun ini juga menjadi problematika dilansir dari (Bana, n.d.) sebanyak $72,8 \%$ siswa mengeluh karena terlalu banyak tugas yang diberikan guru sesuai dengan.

Berdasarkan paparan diatas maka peneliti akan melakukan penelitian tentang analis TPACK guru sekolah dasar dalam pembelajaran di masa pandemi covid-19 di Surakarta. Tujuan dari penelitian ialah untuk mendeskripsikan kemampuan TPACK guru dalam melakukan pembelajaran, mendeskripsikan kendala yang dialami guru dan siswa dalam pembelajaran. Metode yang digunakan dalam penelitian ini adalah menggunakan pendekatan penelitian kualitatif deskriptif. Pendekatan penelitian kualitatif deskriptif ini, peneliti memberikan gambaran berupa deskripsi terhadap seubjek penelitian yang diteliti. Subjek penelitian ini adalah guru sekolah dasar di Surakarta yang diambil sampel 5 kecamatan, setiap kecamatan terdapat 2 sekolahan yakni satu sekolah negeri dan satu lagi sekolah swasta, yang memiliki akreditasi berbeda. Untuk memperjelas peneliti membagi dalam beberapa sub literatur diantaranya: 
5197 Analis TPACK (Technological Pedagogical Content Knowledge) Guru Sekolah Dasar dalam Pembelajaran di Masa Pandemi Covid-19 di Surakarta - Dila Putri Maharani, Hengki Hermawan, Desi Tri Wulandari, Nadia Yuli Ismawarti, Galuh Kancanadana, Ika Candra Sayekti

DOI: https://doi.org/10.31004/basicedu.v5i6.1501

\section{Guru}

Dalam dunia pendidikan terutama di sekolah, guru merupakan salah satu kunci sukses dalam dunia pendidikan. Selaras dengan hal tersebut menurut Undang-undang nomor 14 tahun 2005 tentang guru dan dosen, yang menempatkan kedudukan guru sebagai tenaga profesional sekaligus sebagai agen pembelajaran. Sebagai tenaga profesional, pekerjaan guru hanya dapat dilakukan oleh seseorang yang memiliki kualifikasi akademik, kompetensi, dan sertifikat pendidik sesuai dengan persyaratan untuk setiap jenis dan jenjang pendidikan tertentu (Karwati \& Priansa, 2014b, hal. 61). Setiap guru memiliki perannya, seorang guru sekolah dasar selain menjadi seorang guru pada pembelajaran tematik di kelas, guru juga sebagai wali kelas.

Seorang guru Sekolah Dasar harus bisa menyelam dalam dunia anak, mengetahui karakter anak, memotivasi anak dan melakukan pembelajaran yang aktif, inovatif dan menyenangkan. Dalam pembelajaran yang dilaksanakan seorang guru juga harus handal dalam pengurusan administrasi baik dari rencana pelaksanaan pembelajaran serta memilih atau membuat media yang sesuai dalam pembelajaran.

\section{Pembelajaran}

Pembelajaran merupakan serangkaian kegiatan yang dilaksanakan dalam kegiatan belajar mengajar. Pembelajaran yang baik harus menyiapkan perencanaan dalam pembelajaran. Didalam pembelajaran juga harus menciptakan kenyamanan, memotivasi, dan menciptakan antusiaseme siswa dalam mengikuti pembelajaran, sehingga dapat dikatakan guru tersebut menyenangkan (Karwati \& Priansa, 2014a, hal. 247). Selain itu, guru juga perlu menyiapkan lingkungan belajar sedemikian rupa supaya membuat siswa nyaman untuk belajar mengembangkan dan mempertahankan sikap juara (Hernacki, 2015). Dalam langkah pembelajaran mencakup pendahuluan yang berisikan kegiatan guru mengucapkan salam, berdoa, melakukan presensi, mengulang materi dan menggabungkan materi yang akan diajarkan, melakukan pembiasaan yang baik (nasionalisme). Dalam inti guru dapat menerapkan metode dan model pembelajran yang menyenangkan dan aktif agar siswa dapat belajar mandiri dan guru hanya sebagai fasilitaor saja. Pembelajaran yang aktif akan biasanya akan ditandai dengan ketercapaian dari tujuan pembelajaran (Setyosari, 2014). Pembelajaran dimasa pandemi diharuskan memenuhi protokol yang berlaku. Hal ini memang harus membutuhkan penyesuaian bagi tenaga pendidik di Indonesia. Dalam pelaksanaanya mengharuskan pendidik dan peserta didik untuk berinteraksi dan melakukan transfer pengetahuan secara daring (Herliandry, Nurhasanah, Suban, \& Kuswanto, 2020, hal. 67). Pendidik dan peserta didik dapat menggunakan media atau sosial media seperti Whatsaap, facebook, google classroom yang disesuaikan dengan kondisi dan keadaan yang ada dilapangan. Hal tersebut sejalan dengan bahwa sarana yang mendukung dalam pembelajaran di masa pandemi yang gratis ialah dengan menggunakan fitur, Whatsap, google clashroom, Zeinusm Quipper (Abidah, Hidaayatullaah, Simamora, Fehabutar, \& Mutakinati, 2020).

\section{TPACK}

Kemampuan guru dalam melakukan pembelajaran yang aktif, kreatif, inovatif dan menyenangkan, merupakan langkah yang harus dilakukan oleh seorang pengajar. Seorang guru juga diharuskan mampu dalam mengoperasikan teknologi informasi. Teknologi merupakan peralatan modern yang dapat digunakan untuk mempermudah pekerjaan. Teknologi dalam pendidikan untuk seorang guru ialah pengoperasian komputer atau leptop, pengoperasian gawai.

Kemampuan menerapkan teknologi merupakan tuntutan wajib bagi seorang guru. Koehler, M. J., \& Mishra (2009) menjelaskan bahwa the development of TPACK by teachers is critical to effective teaching with technology. Selaras dengan hal tersebut TPACK atau Technological Pedagogical Content Knowledge yakni pengintegrasian antara teknologi, pedagogi, pengetahuan guru tentang isi/ materi pembelajaran. TPACK menurut (Cox \& Graham, 2009, hal. 60-29) ialah pengetahuan guru tentang cara memfasilitasi siswa dalam pembelajaran melalui pendekatan pedagogik dan teknologi. TPACK dalam dunia pendidikan merupakan kerangka kerja dalam mendesain model pembelajaran dengan mengintegrasikan tiga aspek utama yakni teknologi, pendaogi dan content (Hidayati, Setyosari, \& Soepriyanto, 2018, hal. 292). 
5198 Analis TPACK (Technological Pedagogical Content Knowledge) Guru Sekolah Dasar dalam Pembelajaran di Masa Pandemi Covid-19 di Surakarta - Dila Putri Maharani, Hengki Hermawan, Desi Tri Wulandari, Nadia Yuli Ismawarti, Galuh Kancanadana, Ika Candra Sayekti

DOI: https://doi.org/10.31004/basicedu.v5i6.1501

Berdasarkan hal tersebut, maka dapat disimpulkan bahwa pembelajaran yang berkualitas memerlukan pemahaman yang lebih untuk menggabungkan ketiga aspek tersebut yakni teknologi, pendagogi, dan content serta bagaimana ketiga sumber tersebut dapat diterapkan sesuai dengan konteksnya (Koehler \& Mishra, 2009, hal. 62). Dalam TPACK terbagi kedalam tujuh bagian yakni: Technological knowledge (TK) atau pengetahuan teknologi merupakan pengetahuan tentang berbagai jenis teknologi sebagai alat, proses, maupun sumber, Pedagogical knowledge (PK) atau pengetahuan pedagogik yaitu pengetahuan tentang teori dan praktik dalam perencanaan, proses, dan evaluasi pembelajaran atau bagaimana cara guru mengelola aktivitas didalam kelas untuk mencapai tujuan pembelajaran, Content knowledge (CK) atau pengetahuan konten adalah pengetahuan tentang konten atau materi pelajaran yang harus dipelajari oleh guru dan diajarkan kepada siswa. Pedagogical content knowledge (PCK) atau pengetahuan pedagogik konten merupakan pengetahuan pedagogik yang berhubungan dengan konten khusus, Technological pedagogical knowledge (TPK) atau pengetahuan teknologi pedagogik adalah pengetahuan tentang berbagai teknologi dapat digunakan untuk memfasilitasi belajar dan pembelajaran, Technological content knowledge (TCK) atau pengetahuan teknologi konten adalah pengetahuan tentang timbal balik antara teknologi dengan konten, TPACK atau pengetahuan teknologi pedagogik dan konten adalah pengetahuan tentang penggunaan teknologi yang tepat pada pedagogik yang sesuai untuk mengajarkan suatu konten dengan baik (Rosyid, n.d.)

\section{Covid 19}

Corona Virus Diesease atau yang dikenal dengan COVID-19 merupakan wabah virus yang mulai muncul ditahun 2019, awal kemunculannya di Wuhan Cina. Sejak tanggal 18 Desember 2019 hingga 3 januari 2020 kasus ini meningkat pesat, yang ditandai dengan laporan 44 kasus. Tidak sampai satu bulan virus ini menyebar keberbagai wilayah china, thailand, jepang dan korea selatan (Huang et al., 2020). Virus corona menyebar luas hingga ke berbagai negara didunia tidak terkecuali negara Indonesia. Virus corona sudah menyebabkan banyak korban berjatuahan. Dilansir dari covid19.go.id terdapat 219 negara yang terdapat virus corana, terkonfirmasi 46.840.783 orang yang terpapar dan 1.204.028 korban meninggal dunia karena virus tersebut. Dengan adanya virus tersebut maka tatanan kehidupanpun berubah drastis, tidak terkecuali pendidikan (Tania, 2020). Pembelajaran yang biasanya diadakan dengan tatap muka menjadi virtual (online) di rumah saja, seperti: Work from Home (WFH), School from Home (SFH) Seminar menjadi webinar online dan lain sebagainya.

\section{METODE}

Penelitian yang digunakan dalam penelitian ini adalah penelitian kualitatif. Penelitian kualitatif merupakan penelitian yang dilakukan secara menyeluruh terhadap suatu objek. Peneliti menjadi instrumen utama dalam penelitian, kemudian hasil penelitian dijelaskan dalam bentuk kata-kata yang diperoleh melalui data yang valid (Jaya, 2020, hal. 110). Pendekatan yang digunakan dalam penelitian ini adalah pendekatan kualitatif deskriptif. Menurut Sugiyono (2016) hasil penelitian kualitatif lebih menekankan pada makna dari pada generalisasi. Subjek yang digunakan dalam penelitian ini ialah guru sekolah dasar di Surakarta yang terdiri dari 5 kecamatan yakni Laweyan, Serengan, Pasar Kliwon, Banjar Sari dan Jebres. Dalam setiap kecamatan peneliti mengambil dua sekolahan yakni sekolahan swasta dan negeri. Disetiap sekolah kami mengmbil subjek dua guru yakni satu guru kelas atas dan satu guru kelas bawah yang diambil secara acak. Sehingga dalam satu kecamatan ada empat guru dan dalam satu kabupaten terdapat duapuluh guru.

Pengumpulan data yang diterapkan sebagai pengumpulan data dalam penelitian ini adalah:

\section{Observasi}

Observasi atau pengamatan merupakan suatu metode yang digunakan untuk memperoleh data dengan cara peneliti mencatat informasi sesuai dengan apa yang disaksikan selama penelitian (Amalia \& Sayekti, 2016, hal. 45). Sehingga dalam penelitian yang dilakukan oleh peneliti yakni mengamati melalui group kelas Whatsap, karena pembelajaran dilakukan secara daring. 
5199 Analis TPACK (Technological Pedagogical Content Knowledge) Guru Sekolah Dasar dalam Pembelajaran di Masa Pandemi Covid-19 di Surakarta - Dila Putri Maharani, Hengki Hermawan, Desi Tri Wulandari, Nadia Yuli Ismawarti, Galuh Kancanadana, Ika Candra Sayekti

DOI: https://doi.org/10.31004/basicedu.v5i6.1501

2. Wawancara

Wawancara merupakan teknik yang digunakan untuk membuktikan terhadap informasi atau keterangan yang diperoleh sebelumnya. Wawancara dilakukan dengan mengumpulkan informasi dengan cara mengajukan beberapa pertanyaan (Sutama, 2019, hal. 113) dengan maksud tertentu (Moleong, 2012, hal. 186). Dalam penelitian ini karena masih dalam pandemi dan pemberlakukan pembatasan kegiatan masyarakat/ level 4 maka peneliti meminta informasi kepada narasumber dengan mengajukan pertanyaan via rekam suara.

3. Dokumentasi

Merupakan metode yang digunakan untuk mendapatkan data yang berupa portofolio, arsip, dan laporan. Dalam penelirian ini dokumentasi yang diperlukan ialah RPP, Silabus, Prota, Promes. Teknik analisis data kualitatif menurut Arief Furchan (2004, hal. 34) dilakukakan melalui beberapa tahapan yakni:1). Menelaah seluruh data yang tersedia dari berbagai sumber yang diperoleh dari hasil pengumpulan data. Tahap ini peneliti menganalisis data dari berbagai sumber baik wawancara secara langsung, pengsisian angket dan rekam suara. 2). Mengadakan reduksi data yang dilakukan dengan jalan merangkum, proses dengan pernyataan-pernyataan. Dalam tahap ini peneliti merangkum jawaban dari berbagai narasumber sehingga mendapatkan data yang dibutuhkan saja. 3). Penyajian data, dalam tahap ini peneliti menyajikan data data yang diperoleh dalam bentuk teks naratif dari catatan lapangan. 4). Pemeriksaan keabsahan data, kemudian ketahap penafsiran data dalam mengolah hasil sementara menjadi teori sumatif melaui metode tertentu.

\section{HASIL DAN PEMBAHASAN}

Penelitian ini bertujuan untuk mendiskripsikan TPACK Guru dalam pembelajaran tematik di masa pandemi, mendiskripsikan hambatan yang dialami guru dan solusi apa yang dilakukan oleh guru dengan hasil data sebagai berikut:

\begin{tabular}{|c|c|c|c|c|}
\hline No $\begin{array}{c}\text { Pengetahuan } \\
\text { Dasar }\end{array}$ & Komposisi & Keterangan & Hambatan & Solusi \\
\hline $\begin{array}{ll}1 & \mathrm{TK}\end{array}$ & $20 / 20$ & $\begin{array}{l}\text { Responden telah mengusai } \\
\text { tekhnologi yang digunakan } \\
\text { dalam memfasilitasi anak- } \\
\text { anak dalam pembelajaran } \\
\text { online. Walau berbeda } \\
\text { antara guru di sekolah } \\
\text { A,B,C,D dst. Mayoritas } \\
\text { menggunakan Watshap } \\
\text { sebagai aplokasi utama } \\
\text { dalam pembelajan daring } \\
\text { di masa pandemi. Namun, } \\
\text { terkadang ada juga yang } \\
\text { menggunakan g.meet } \\
\text { dalam menyampaikan } \\
\text { materi pembelajaran. }\end{array}$ & $\begin{array}{l}\text { 1. Keterbatasan } \\
\text { kuota internet. } \\
\text { 2. Keterbatasan } \\
\text { ruang } \\
\text { penyimpanan. }\end{array}$ & $\begin{array}{l}\text { 1. Jangka waktu yang } \\
\text { digunakan tidak terlalu } \\
\text { lama. } \\
\text { 2. Menghapus file atau } \\
\text { dokumen yang sudah } \\
\text { tidak digunakan. }\end{array}$ \\
\hline $2 \mathrm{CK}$ & $20 / 20$ & $\begin{array}{l}\text { Buku yang digunakan } \\
\text { disetiap sekolah berbeda, } \\
\text { ada yang menggunakan } \\
\text { buku tematik K13 terbitan } \\
\text { kemendikbud, Erlangga, } \\
\text { Yudistira. Pemahaman } \\
\text { guru mengenai materi yang } \\
\text { disampaikan sangat baik } \\
\text { karena didukung dengan } \\
\text { pengalaman mengajarnya. }\end{array}$ & $\begin{array}{l}\text { 1. Tidak semua } \\
\text { materi yang ada } \\
\text { dibuku dapat } \\
\text { tersampaikan. } \\
\text { 2. Sulitnya } \\
\text { pemahaman anak } \\
\text { terhadap materi } \\
\text { yang disiapkan }\end{array}$ & $\begin{array}{l}\text { 1. Menyampaikan inti } \\
\text { materi dan meminta anak } \\
\text { untuk membaca ulang. } \\
\text { 2. Meminta anak untuk } \\
\text { merangku atau menulis } \\
\text { hal-hal penting pada } \\
\text { materi yang telah } \\
\text { dipelajari. }\end{array}$ \\
\hline
\end{tabular}


5200 Analis TPACK (Technological Pedagogical Content Knowledge) Guru Sekolah Dasar dalam Pembelajaran di Masa Pandemi Covid-19 di Surakarta - Dila Putri Maharani, Hengki Hermawan, Desi Tri Wulandari, Nadia Yuli Ismawarti, Galuh Kancanadana, Ika Candra Sayekti

DOI: https://doi.org/10.31004/basicedu.v5i6.1501

\begin{tabular}{|c|c|c|c|c|}
\hline $\begin{array}{ll}3 \mathrm{PK} \\
\end{array}$ & $20 / 20$ & $\begin{array}{l}\text { Responden melakukan } \\
\text { pembelajaran daring } \\
\text { hampir sama dengan } \\
\text { pembelajarn luring. Hanya } \\
\text { saja yang membedakan } \\
\text { adalah tidak bertemu } \\
\text { langsung. Apabila ada } \\
\text { TMO (Tatap Muka Online) } \\
\text { melalui zoom atau g,meet } \\
\text { maka guru juga akan } \\
\text { melakukan pembukaan } \\
\text { seperti salam, sapa, } \\
\text { bernyanyi dst. namun } \\
\text { memang kebanyakan guru } \\
\text { memberikan materi } \\
\text { melalui grup watshap yang } \\
\text { berupa teks. }\end{array}$ & $\begin{array}{l}\text { 1. Pengelolaan kelas } \\
\text { yang terkadang } \\
\text { gagal karena } \\
\text { apabila } \\
\text { menggunakan } \\
\text { google meet } \\
\text { maka anak akan } \\
\text { ada saja yang } \\
\text { brisik dan tidak } \\
\text { menutup } \\
\text { microphon dan } \\
\text { itu yang membuat } \\
\text { waktu terbuang } \\
\text { untuk } \\
\text { menenangkan. } \\
\text { Apabila } \\
\text { menggunakan } \\
\text { zoom dalam } \\
\text { waktu } 45 \text { menit } \\
\text { zoom akan mati } \\
\text { dan harus } \\
\text { membuat room } \\
\text { baru. }\end{array}$ & $\begin{array}{l}\text { 1. Menerapkan peraturan } \\
\text { TMO dengan tegas, } \\
\text { menyampaikan peraturan } \\
\text { di awal TMO sebelum } \\
\text { pelaksanaan TMO } \\
\text { dilakukan. Seperti } \\
\text { apabila menggunakan } \\
\text { zoom maka } 5 \text { menit } \\
\text { sebelum zoom link baru } \\
\text { dibagikan dan anak } \\
\text { diminta untuk segera } \\
\text { masuk kedalam room. }\end{array}$ \\
\hline 4 ТРК & $20 / 20$ & $\begin{array}{l}\text { Pengetahuan guru } \\
\text { mengenai materi ajar yang } \\
\text { akan disampaikan } \\
\text { berhubungan dengan } \\
\text { media apa yang yang tepat } \\
\text { untuk di gunakan guru } \\
\text { dalam menyampaikan } \\
\text { materi seperti penggunaan } \\
\text { link youtube agar anak } \\
\text { mendapatkan audio visual } \\
\text { dari pembelajaran materi } \\
\text { tersebut. Selain materi } \\
\text { penilaian dilakukan dengan } \\
\text { mengumpulkan tugas } \\
\text { setiap minggunya atau } \\
\text { mengerjakan soal melalui } \\
\text { google form. }\end{array}$ & $\begin{array}{l}\text { Keterbatasan kuota } \\
\text { internet yang } \\
\text { dimiliki wali murid } \\
\text { dan guru untuk } \\
\text { mengakses youtube } \\
\text { apabila terlalu } \\
\text { sering. }\end{array}$ & $\begin{array}{l}\text { Mengatur jadwal atau waktu } \\
\text { yang tepat agar tidak terjadi } \\
\text { pemborosan kuota dengan } \\
\text { menentukan materi mana } \\
\text { saja yang memerlukan } \\
\text { media youtube dan materi } \\
\text { mana yang tidak } \\
\text { memerlukan media youtube. }\end{array}$ \\
\hline 5 TCK & $20 / 20$ & $\begin{array}{l}\text { Materi yang sudah dikuasai } \\
\text { guru, disampaikan kepada } \\
\text { anak-anak didiknya } \\
\text { melalui aplikasi yang } \\
\text { mendukung. Seperti, WA } \\
\text { Group, link youtube, } \\
\text { pembuatan video } \\
\text { pembelajaran, ppt } \\
\text { bernarasi. }\end{array}$ & $\begin{array}{l}\text { Memory gawai yang } \\
\text { cepat penuh. } \\
\text { Keterbatasan guru } \\
\text { dalam penggunaan } \\
\text { aplikasi edit video. }\end{array}$ & $\begin{array}{l}\text { Menghapus file dan } \\
\text { dokumen yang tidak } \\
\text { penting, belajar } \\
\text { menggunakan aplikasi edit } \\
\text { video melalui tutorial } \\
\text { youtube atau teman sejawat. }\end{array}$ \\
\hline 6 PCK & $20 / 20$ & $\begin{array}{l}\text { Penyampaian materi dalam } \\
\text { pembelajaran daring } \\
\text { dilakukan hampir sama }\end{array}$ & $\begin{array}{l}\text { Tidak semua materi } \\
\text { dapat disampaikan } \\
\text { dengan baik. Ada }\end{array}$ & $\begin{array}{l}\text { Apabila materi dikira dapat } \\
\text { dilakukan siswa dirumah, } \\
\text { maka responden akan }\end{array}$ \\
\hline
\end{tabular}


5201 Analis TPACK (Technological Pedagogical Content Knowledge) Guru Sekolah Dasar dalam Pembelajaran di Masa Pandemi Covid-19 di Surakarta - Dila Putri Maharani, Hengki Hermawan, Desi Tri Wulandari, Nadia Yuli Ismawarti, Galuh Kancanadana, Ika Candra Sayekti

DOI: https://doi.org/10.31004/basicedu.v5i6.1501

\begin{tabular}{|c|c|c|c|c|}
\hline & & $\begin{array}{l}\text { dengan pembelajaraan } \\
\text { tatap muka, hanya saja } \\
\text { tidak bisa betemu } \\
\text { langsung. Responden } \\
\text { mampu menyampaikan } \\
\text { materi dengan baik dan } \\
\text { sesuai dengan KI KD. }\end{array}$ & $\begin{array}{l}\text { beberapa materi } \\
\text { yang membutuhkan } \\
\text { pertemuan antara } \\
\text { responden dan murid } \\
\text { namun karena } \\
\text { keadaan tidak bisa, } \\
\text { seperti praktek } \\
\text { mencangkok, } \\
\text { menanam kacang } \\
\text { hijau dll. }\end{array}$ & $\begin{array}{l}\text { memberikan projek untuk } \\
\text { dirumah seperti menanam } \\
\text { biji kacang hijau. }\end{array}$ \\
\hline 7 TPACK & $20 / 20$ & $\begin{array}{l}\text { Sebagian besar responden } \\
\text { baru mengetahui atau baru } \\
\text { mendengar istilah TPACK. } \\
\text { Oleh sebab itu, maka } \\
\text { banyak responden yang } \\
\text { tidak mengerti apa itu } \\
\text { TPACK walau terkadang } \\
\text { dilapangan saat mereka } \\
\text { mengajar, komponen- } \\
\text { komponen TPACK } \\
\text { tersebut sudah ada. } \\
\text { Sebagian besar guru juga } \\
\text { sudah menerapkan } \\
\text { pengetahuan TPACK } \\
\text { walaupun tidak mereka } \\
\text { sadari yang berupa bentuk } \\
\text { lain, seperti guru sudah } \\
\text { mampu menggunakan atau } \\
\text { meguasai } 1 \text { media yang } \\
\text { paten digunakan seperti } \\
\text { whatsaap. }\end{array}$ & $\begin{array}{l}\text { Tidak semua } \\
\text { responden dapat } \\
\text { menggunakan zoom, } \\
\text { gmeet, }\end{array}$ & $\begin{array}{l}\text { Memilih menggunakan } \\
\text { video call dengan kelompok } \\
\text { kecil agar pembelajaran } \\
\text { tetap berjalan. }\end{array}$ \\
\hline
\end{tabular}

TPACK merupakan suatu bentuk pengetahuan yang kompleks dan sangat penting bagi guru. TPACK adalah pengetahuan yang dibutuhkan agar seorang guru dapat menggunakan teknologi yang tepat, yang didasarkan pada analisis karakter materi dan analisis pada aspek pedagogi (Mishra dan Koehler, 2006). TPACK mensyaratkan adanya multi interaksi yang unik dan sinergi antara materi, pedagogi dan teknologi (Mishra, dkk., 2008). Technological knowledge (TK) atau pengetahuan teknologi merupakan pengetahuan tentang berbagai jenis teknologi sebagai alat, proses, maupun sumber.

Pedagogical knowledge (PK) atau pengetahuan pedagogik yaitu pengetahuan tentang teori dan praktik dalam perencanaan, proses, dan evaluasi pembelajaran. Content knowledge $(\mathrm{CK})$ atau pengetahuan konten adalah pengetahuan tentang konten atau materi pelajaran yang harus dipelajari oleh guru dan diajarkan kepada siswa. Pedagogical content knowledge (PCK) atau pengetahuan pedagogik konten merupakan pengetahuan pedagogik yang berhubungan dengan konten khusus Shulman (dalam Rahmadi 2019). Technological content knowledge (TCK) atau pengetahuan teknologi konten adalah pengetahuan tentang timbal balik antara teknologi dengan konten. Technological pedagogical knowledge (TPK) atau pengetahuan teknologi pedagogik adalah pengetahuan tentang berbagai teknologi dapat digunakan untuk memfasilitasi belajar dan pembelajaran. TPACK atau pengetahuan teknologi pedagogik dan konten adalah pengetahuan tentang penggunaan teknologi yang tepat pada pedagogik yang sesuai untuk mengajarkan suatu konten dengan baik.

Pengetahuan TPACK guru sekolah dasar di surakarta terbentuk karena terpaksa. Sebab apabila guru tidak memaksakan diri untuk mengikuti canggihnya tekhnologi maka guru akan lebih kesusahan dan repot. 
5202 Analis TPACK (Technological Pedagogical Content Knowledge) Guru Sekolah Dasar dalam Pembelajaran di Masa Pandemi Covid-19 di Surakarta - Dila Putri Maharani, Hengki Hermawan, Desi Tri Wulandari, Nadia Yuli Ismawarti, Galuh Kancanadana, Ika Candra Sayekti

DOI: https://doi.org/10.31004/basicedu.v5i6.1501

TPACK juga terdiri dari enam pengetahuan dasar yang telah dibahas diatas. Sehingga dari hasil penelitian diatas tertera bahwasannya penerapan pengetahuan TPACK guru di surakarta adalah baik walau terkadang guru tidak menyadari bahwa hal tersebut sudah dilakukan. Hambatan yang terjadi pada pembelajaran daring antara lain beberapa guru sudah menginjak umur 40 tahun yang menyebabkan keterlambatan dalam memahami teknology dan memilih untuk merepotkan sedikit dirinya sendiri sebagai solusi agar pembelajaran terlaksana. Ketujuh pengetahuan tersebut perlu dikuasai oleh calon guru masa depan agar menjadi guru professional sesuai harapan.

\section{KESIMPULAN}

Berdasarkan hasil penelitian yang telah dilakukan maka terdapat berbagai kesimpulan yakni dalam kemampuan TK, CK, PK, TCK, PCK, TPACK Sudah terdapat dalam pengajaran guru di Surakarta. Mereka menggunakan teknologi atau aplikasi WA yang banyak digunakan oleh siswa dan orangtua. Penggunaan video pembelajaran dan zoom meeting dan web meeting satu bulan sekali juga digunakan dalam evaluasi pembelajaran. Hambatan yang dialami oleh responden seperti keluhan kuota internet cepat habis, memori gawai yang cepat penuh, menentukan jadwal tatap muka daring, adapun yang tidak memiliki gawai. Solusi untuk mengatasinya yakni melakukan tatap muka yang singkat, menghapus file-file yang sudah tidak digunakan, membuat video pembelajaran yang tidak terlalu panjang dan dengan kualitas yang rendah namun masih bisa dilihat dan didengar siswa, melakaukan tatap muka pagi hari sebelum orang tua bekerja atau malam setelah orang tua bekerja, meminta anak datang ke sekolah satu pekan sekali dengan mematuhi protokol kesehatan agar diberikan penguatan atau pemahan dalam memahami materi.

\section{DAFTAR PUSTAKA}

Abidah, A., Hidaayatullaah, H. N., Simamora, R. M., Fehabutar, D., \& Mutakinati, L. (2020). The Impact of Covid-19 to Indonesian Education and Its Relation to the Philosophy of "Merdeka Belajar." Studies in Philosophy of Science and Education, 1(1), 38-49. https://doi.org/10.46627/sipose.v1i1.9

Amalia, T. F., \& Sayekti, I. C. (2016). Pengembangan Pendidikan Di SD Islam Internasional Al-Abidin Surakarta Dalam Menghadapi (Masyarakat Ekonomi ASEAN) MEA. Profesi Pendidikan Dasar, 3(1).

Bana, M. F. (n.d.). Satu Bulan Belajar Online, 72,8 \% Siswa Mengeluh Penumpukan Tugas.

Cox, S., \& Graham, C. R. (2009). Diagram TOACK in Practice: Using an Elaborated Model of the TPACK Framework to Analyze and Depict Teacher Knowledge. TechTrends, 5(5).

Furchan, A. (2004). Pengantar Penelitian dalam Pendidikan. Yogyakarta: Pustaka Pelajar Offset.

Herliandry, L. D., Nurhasanah, N., Suban, M. E., \& Kuswanto, H. (2020). Pembelajaran Pada Masa Pandemi Covid-19. JTP - Jurnal Teknologi Pendidikan, 22(1), 65-70. https://doi.org/10.21009/jtp.v22i1.15286

Hernacki, B. D. \& M. (2015). Quantum Learning (2 ed.). Bandung: Dell Publising.

Hidayati, N., Setyosari, P., \& Soepriyanto, Y. (2018). Kompetensi Technogical Pedagogical Content Knowledge (TPACK) Guru Soshum Setingkat SMA. JKTP, 1(4).

Huang, C., Wang, Y., Li, X., Ren, L., Zhao, J., \& Hu, Y. (2020). Clinical Features of Patients Infected with 2019 Novel Coronavirus in Wuhan, China. Lancet, 395(10223), 497-506.

Jaya, I. M. L. M. (2020). Metode Penelitian Kuantitatif dan Kualitatif. Yogyakarta: QUADRANT.

Karwati, E., \& Priansa, D. J. (2014a). Manajemen Kelas (Classroom Management) Guru Profesional yang Inspiratif, Kreatif, Menyenangkan dan Berprestasi. Bandung: Alfabeta.

Karwati, E., \& Priansa, D. J. (2014b). MANAJEMEN KELAS (Classroom Management) Guru Profesional yang Inspiratif, Kreatif, Menyenangkan dan Berprestasi. Bandung: ALFABETA, cv. 
5203 Analis TPACK (Technological Pedagogical Content Knowledge) Guru Sekolah Dasar dalam Pembelajaran di Masa Pandemi Covid-19 di Surakarta - Dila Putri Maharani, Hengki Hermawan, Desi Tri Wulandari, Nadia Yuli Ismawarti, Galuh Kancanadana, Ika Candra Sayekti DOI: https://doi.org/10.31004/basicedu.v5i6.1501

Koehler, M. J., \& Mishra, P. (2009). Koehler, M. J., \& Mishra, P. Michigan State University, 9(1), 60-70.

Koehler, M. J., \& Mishra, P. (2009). What is Teachnological Pedagogical Content Knowledge? Contemporary Issues in Technology and Teacher Education, 9(1).

Mar'ah, N. K., Rusilowati, A., \& Sumami, W. (2020). Perubahan Proses Pembelajaran Daring Pada Siswa Sekolah Dasar di Tengah Pandemi Covid-19. In Seminar Nasional Pascasarjana 2020. Semarang.

Moleong, L. J. (2012). Metode Penelitian Kualitatif. Bandung: PT Remaja Rosdakarya.

Rosyid, A. (n.d.). Technological Pedagogical Content Knowledge: Sebuah Kerangka Pengetahuan Bagi Guru Indonesia Di Era MEA. FKIP UNS Journal.

Setyosari, P. (2014). Menciptakan Pembelajaran yang Efektif dan Berkualitas. Jurnal Inovasi dan Teknologi Pembelajaran, 1(1).

Sugiyono, P. D. (2016). Metode penelitian kuantitatif, kualitatif,dan R\&D. Alfabeta, cv.

Sutama. (2019). Metode Penelitian Pendidikan. Kartasura: CV.Jasmine.

Tania, A. Y. (2020). Analisis Pembelajaran Daring Selama Pandemi Covid-19 Di Sekolah Dasar Surakarta. Jenius: Jurnal of Education Policy and Elementary Education Issues, 1(2), 1-8. 